Care: Jurnal Ilmiah Ilmu Kesehatan Vol .7, No.2, 2019, hal 1-6

Tersedia online di https://jurnal.unitri.ac.id/index.php/care

ISSN 2527-8487 (online)

ISSN 2089-4503 (cetak)

\title{
PENGARUH PIJAT BAYI TERHADAP DURASI TIDUR PADA BAYI UMUR 1-3 BULAN
}

\author{
Ni Gusti Ayu Pramita Aswitami ${ }^{1)}$, Ni Putu Mirah Yunita Udayani ${ }^{2)}$ \\ ${ }^{1), 2)}$ STIKES Bina Usada Bali,Jln.Kubu Gunung Tegal Jaya Dalung \\ E-mail : tamichant@yahoo.com
}

\begin{abstract}
Sleep is the baby's main requirement because when the baby falls asleep growth and development will be optimal and there will be an increase in brain function and body metabolism. In infants aged 1-3 months have a sleep duration of 14 hours-18 hours per day. Baby's growth and development will be less optimal if there is a sleep disorder. Baby massage is one way to overcome the problem of sleeping in a baby. Baby massage is a gentle rubbing motion on the surface of the baby's body from face to foot. This massage will help relax the baby's muscles and facilitate blood circulation so that the baby becomes calmer and sleeps more soundly. This study aims to determine the effect of infant massage on sleep duration in infants aged 1-3 months. The design of this study used a pre-experimental design with the design of one group pretest-posttest design without a control group. Samples are infants aged 1-3 months, totaling 42 people selected by purposive sampling. The variables measured in this study were infant massage and sleep duration. This study used a statistical test paired t-test (a $=0.05)$. The results of this study are that there is an effect of infant massage on the duration of infant sleep, this is confirmed by the value of Wilcoxon test with sig 0,000 which then tested the hypothesis with a value of a $=0.05$. With a sig value of $0,000<0,05$, it is known that $\mathrm{Ho}$ is rejected and Ha is accepted. So it can be concluded that there is the effect of infant massage on the duration of infant sleep so that the role of midwives is needed to develop skills in providing baby massage services especially to parents and the community in general.
\end{abstract}

Keywords: Sleep duration; Baby Massage.

\begin{abstract}
ABSTRAK
Tidur adalah kebutuhan utama bayi karena pada saat bayi tertidur tumbuh kembang akan optimal serta terjadi peningkatan fungsi otak dan metabolisme tubuh. Pada bayi usia 1-3 bulan memiliki durasi tidur 14 jam-18 jam per hari. Pertumbuhan dan perkembangan bayi akan menjadi kurang optimal apabila terjadi gangguan tidur. Pijat bayi adalah salah satu cara untuk mengatasi permasalahan tidur pada bayi. Pijat bayi merupakan gerakan mengusap secara gentle pada permukaan tubuh bayi dari wajah hingga kaki. Pemijatan ini akan membantu merilekskan otot bayi serta melancarkan sirkulasi darah sehingga bayi menjadi lebih tenang dan tertidur lebih pulas. Penelitian ini bertujuan untuk mengetahui pengaruh pijat bayi terhadap durasi tidur pada bayi umur 1-3 bulan. Desain penelitian ini menggunakan pra eksperimen design

Cara mengutip: Aswitami, Ni Gusti AP., \& Udayani, Ni Putu MY.(2019).Motivasi Pengaruh Pijat Bayi Terhadap Durasi Tidur Pada Bayi Umur 1-3 Bulan. Care:Jurnal Ilmiah Ilmu Kesehatan, 7(2), 1-6

Retrieved from https://jurnal.unitri.ac.id/index.php/care/article/view/1035
\end{abstract}


dengan rancangan one group pretest-posttest design tanpa kelompok kontrol. Sampel adalah bayi usia 1-3 bulan yang berjumlah 42 orang yang dipilih secara purposive sampling. Variabel yang diukur dalam penelitian ini adalah pijat bayi dan durasi tidur. Penelitian ini ini menggunakan uji statistik paired t-test $(a=0,05)$. Hasil penelitian ini adalah terdapat pengaruh pijat bayi terhadap durasi tidur bayi, hal ini dipertegas nilai uji wilcoxon dengan sig 0,000 yang selanjutnya dilakukan pengujian hipotesis dengan nilai $\alpha=0,05$. Dengan nilai sig $0,000<0,05$ diketahui bahwa Ho ditolak dan Ha diterima. Maka dapat disimpulkan ada pengaruh pijat bayi terhadap durasi tidur bayi sehingga peran bidan dibutuhkan untuk mengembangkan keterampilan dalam memberikan pelayanan pijat bayi khususnya kepada orangtua dan masyarakat pada umumnya.

Kata Kunci : Durasi tidur; Pijat bayi.

\section{PENDAHULUAN}

Bayi memiliki tiga kebutuhan yang harus dipenuhi oleh orang tua, yaitu kebutuhan fisik-biologis yang berguna untuk pertumbuhan otak, sistem sensorik, serta motorik. Kecerdasan emosi interpersonal dan intrapersonal melalui kebutuhan kasih sayang, serta kebutuhan stimulus atau rangsangan untuk meningkatkan mekanisme kerja system sensorik dan motorik (Maharani, 2012). Hal terpenting dalam tumbuh kembang anak adalah adanya rangsangan atau stimulus (Ngastiyah, 2013).

Salah satu bentuk stimulasi pada bayi, yaitu stimulasi sentuhan dengan cara pijat bayi. Menurut (Nedra, W. Soedjatmiko \& Firmansyah, 2006) pijat bayi mengandung unsur kasih saying secara non verbal yang dapat merangsang pertumbuhan sel-sel dan fungsi otak bayi. Pijat bayi telah dikenal sejak lama yang kemudian digali kembali melalui gerakan atau "sentuhan" bersumber dari penelitian-penelitian dari dunia kesehatan oleh para ahli neonatologi, neuro dan psychis anak (Subakti, Y. \& Anggraini, D. R., 2008).

Pijat adalah terapi sentuh tertua yang dikenal manusia dan dipakai dalam perawatan kesehatan dan pengobatan. Pemberian pijat pada bayi baru lahir diharapkan dapat meningkatkan durasi tidur pada bayi. Pijat bayi mempengaruhi kerja system saraf sehingga memperbaiki motilitas saluran cerna termasuk pengosongan lambung sehingga mengakibatkan penyerapan makanan lebih baik dan meningkatkan kualitas tidur pada bayi. Maka dari itu pijat bayi dikatakan memiliki banyak keuntungan dari segi kesehatan (Roesli, 2010).

Salah satu penelitian yang dilakukan oleh (Lestari, 2014) mengenai pengaruh pijat terhadap tingkat pemenuhan kebutuhan tidur bayi usia 3 sampai 6 bulan di 
Care: Jurnal Ilmiah Ilmu Kesehatan Vol .7, No.2, 2019, hal 1-6

kecamatan sentolo kulon progo pengaruh pijat bayi terhadap durasi tidur menyatakan bahwa mengatakan bahwa pijat bayi sangat penting dalam menunjang tumbuh kembang bayi. Bayi memiliki selsel syaraf yang belum terbentuk sempurna. Pertumbuhan dan perkembangan pada bayi terjadi saat bayi tertidur sehingga bayi memerlukan waktu tidur yang lebih lama dari orang dewasa untuk kematangan selsel syaraf, pembentukan sel-sel otak serta kematangan organ-organ pada bayi.

Untuk mencapai kematangan sel-sel pada otak bayi, maka otak bayi memerlukan waktu 3 kali lipat dari keadaan saat lahir dan sekitar $80 \%$ dari sel-sel otak orang dewasa pada tahun pertama. Tentunya keadaan ini hanya terjadi sekali dalam seumur hidup. Dan momen tidur pada bayi harus diupayakan seoptimal mungkin karena pertumbuhan dan perkembangan sel-sel terjadi pada saat bayi tertidur. Maka dari itu kebutuhan tidur bayi harus benarbenar terpenuhi. Menurut (Roesli, 2010) dengan pijat bayi maka dapat meningkatkan kadar melatonin yang berperan membuat bayi tertidur lebih lelap di malam hari.

\section{METODE PENELITIAN}

Penelitian ini menggunakan desain penelitian pre eksperimen yang merupakan penelitian analitik. Penelitian ini menggunakan pre test dan post test design. Pada penelitian ini untuk mengetahui bayi. Populasi dalam penelitian ini bayi dengan umur 1-3 bulan di BPM Ida Ayu Putu Suartika, Amd.Keb. Besar populasi bayi umur 1-3 bulan pada bulan FebruariMaret tahun 2017 sebanyak 42 bayi. Seluruh populasi dijadikan sebagai sampel. Sebelumnya subjek diobervasi durasi tidurnya dengan kategori baik (jika durasi tidur $>14$ yang dihitung dalam 24 jam) dan kurang (jika durasi tidur bayi kurang dari $>$ 14 jam dalam 24 jam). Kemudian subjek diberikan perlakuan yaitu pijat bayi sebanyak dua kali dalam 1 minggu selama 4 minggu. Setelah itu dilakukan observasi dan pengukuran durasi tidur dengan kategori yang sama. Kemudian hasil pre dan post dianalisis menggunakan SPSS. Penelitian ini menggunakan rancangan analisis analisis univariat dan bivariat untuk menganalisis hubungan variabel bebas dan variabel terikat.

\section{HASIL}

Berikut adalah analisis univariat yang dilakukan untuk mengetahui durasi tidur sebelum mendapat Pemijatan

Tabel 1. Durasi Tidur Sebelum Mendapat Pemijatan

\begin{tabular}{ccc}
\hline Skala Masa Tidur & Jumlah & $\mathbf{\%}$ \\
\hline Kurang & 35 & 83,33 \\
Baik & 7 & 16,67 \\
\hline Total & 42 & 100 \\
\hline
\end{tabular}


Berdasarkan Tabel 1 diatas terlihat bahwa terdapat sebagian besar bayi memiliki durasi tidur kurang dari 14 jam yaitu 35 bayi (83,33\%) dibandingkan dengan bayi yang memiliki durasi tidur $>=14$ jam yaitu 7 bayi (16,67\%) sebelum diberikan pijat bayi.

Berdasarkan Tabel 2 terlihat bahwa terdapat sebagian besar bayi yang mendapat Pemijatan memiliki durasi tidur baik yaitu
36 bayi $(85,71 \%)$. Berikut adalah analisis bivariat yaitu analisis untuk mengukur perbedaan durasi tidur sebelum dan sesudah diberi Pemijatan

Tabel 2. Durasi Tidur Setelah Mendapat Pemijatan

\begin{tabular}{ccc}
\hline Skala Masa Tidur & Jumlah & $\mathbf{0}$ \\
\hline Kurang & 6 & 14,29 \\
Baik & 36 & 85,71 \\
\hline Total & 42 & 100
\end{tabular}

Tabel 3. Perbedaan Tingkat Durasi Tidur Bayi sebelum dan setelah diberikan Pemijatan

\begin{tabular}{|c|c|c|c|c|c|}
\hline \multirow[t]{3}{*}{ Pijat Bayi } & \multicolumn{4}{|c|}{ Durasi Tidur Bayi } & \multirow[t]{2}{*}{ Pre-Post } \\
\hline & & & & & \\
\hline & f & $\%$ & f & $\%$ & \\
\hline Sebelum & 35 & 83,3 & 7 & 16,7 & \\
\hline Sesudah & 6 & 14,3 & 36 & 85,7 & \\
\hline Z-Sig & & & & & $\begin{array}{r}-5,385 \\
0,000\end{array}$ \\
\hline
\end{tabular}

Berdasarkan tabel 3 dengan menggunakan uji statistic Wilcoxon Match Pair diperoleh bahwa nilai $\mathrm{p}$ value $0,000<\alpha=0,05$, sehingga Ho ditolak, Ha diterima artinya ada pengaruh pijat bayi terhadap durasi tidur bayi.

\section{PEMBAHASAN}

Tidur merupakan kebutuhan utama bagi seorang bayi. Pada bayi selain kualitas, kuantitas juga penting untuk pertumbuhan dan perkembangan bayi (Aziz, A., \& Hidayat, 2007). Berdasarkan hasil penelitian yang dilakukan di BPM Ida Ayu Putu Suartika, Amd. Keb diketahui bahwa sebelum mendapat pijat bayi terdapat 35 bayi
(83,33\%) durasi tidur kurang dan 7 bayi 16,67\% ) memiliki durasi tidur baik.

Hasil penelitian diketahui bahwa terjadi kenaikan durasi tidur bayi setelah diberikan pemijatan sebanyak 36 bayi $(85,71 \%$ ) ini berarti dari hasil penelitian didapat bahwa nilai mean pijat bayi terhadap peningkatan durasi tidur sebelum diberikan perlakuan (pretest) yaitu 1,167 dengan standar deviasi $=0,377$. Nilai posttest mean yaitu 1,857 dengan standar deviasi $=0,354$. Hasil uji statistik wilcoxon didapat nilai $\mathrm{p}=0,000<$ $\alpha=<0,05$ yang artinya terdapat pengaruh yang signifikan pijat bayi terhadap 
Care: Jurnal Ilmiah Ilmu Kesehatan Vol .7, No.2, 2019, hal 1-6

peningkatan durasi tidur bayi. Hasil di atas menggambarkan bahwa pijat bayi sangat berpengaruh terhadap peningkatan durasi tidur bayi, hal ini menunjukkan bahwa pada bayi yang dipijat dapat meningkatkan produksi enzim penyerapan, peningkatan neurotransmitter serotonin serta meningkatkan imunitas tubuh dan mengakibatkan terjadinya perubahan pada gelombang otak yang menyebabkan bayi dapat tertidur lebih lelap. Itu sebabnya mengapa pola tidur bayi akan lebih baik setelah mendapat pemijatan.

Saat bayi tertidur terjadi pertumbuhan dan pematangan pada sel-sel otak dan terjadi peningkatan produksi growth hormone yang memiliki peran terhadap pertumbuhan dan perkembangan bayi secara fisik dan psikis.

Oleh karena itu penting kualitas dan kuantitas tidur bayi untuk diaga agar optimal. Penilaian kualitas tidur pada bayi dapat dilihat dari sering atau tidaknya bayi terbangun pada satu siklus tidur. Melalui pijat bayi, kualitas dan kuantitas tidur bayi meningkat. Hal ini terjadi karena melalui pijat bayi akan menstimulus pengeluaran endhorpine hormone yang menyebabkan bayi menjadi rileks dan tenang (Prasetyono, 2009). Penelitian serupa yang dilakukan oleh (Kusumastuti, N. A., Tamtomo, D., \& Salimo, 2016) menyatakan terdapat pengaruh pijat bayi terhadap kualitas tidur dan peningkatan perkembangan motorik kasar pada bayi umur 1-3 bulan. Hal ini dikarenakan terjadi peningkatan kada aktivitas pada neurotransmitter serotonin yang dihasilkan setelah pemijatan sehingga terjadi penurunan hormone adrenalin yang membuat bayi menjadi tenang dan rileks.penelitian lainnya menyatakan bayi diyakini merupakan salah satu stimulus sentuhan (touch) yang bisa membantu mengoptimalkan tumbuh kembang bayi. Menurut penelitian (Shofa, L., \& Yunani, 2014) bayi yang tidak dipijat memiliki kualitas dan kuantitas tidur yang kurang sehingga lebih mudah rewel dan mudah terbangun di malam hari. Hal ini tentu saja mempengaruhi lama tidur bayi yang kurang optimal dan memiliki efek pada pertumbuhan dan perkembangan bayi.

\section{KESIMPULAN}

Berdasarkan hasil penelitian dengan menggunakan uji statistic diperoleh nilai $p$ value sebesar 0,000 lebih kecil dari $\alpha 0,05$ yang artinya ada pengaruh yang signifikan pijat bayi terhadap peningkatan durasi tidur bayi di BPM Ida Ayu Putu Suartika, Amd. Keb. Hasil penelitian ini dapat diimplementasikan oleh tenaga kesehatan, khususnya bidan untuk memberikan pelayanan kesehatan pada bayi 1-3 bulan dengan melakukan pijat bayi dan poematauan pertumbuhan serta perkembangan bayi. 


\section{UCAPAN TERIMAKASIH}

Penulis mengucapkan terimakasih kepada bidan Ida Ayu Putu Suartika yang telah memberikan ijin tempat penelitian dan kepada institusi STIKES Bina Usada Bali yang telah memberikan dukungan sarana dan prasarana dalam pelaksanaan penelitian ini.

\section{REFERENSI}

Aziz, A., \& Hidayat, A. (2007). Metode penelitian keperawatan dan teknik analisis data. Jakarta: Salemba Medika.

Kusumastuti, N. A., Tamtomo, D., \& Salimo, H. (2016). Effect of Massage on Sleep Quality and Motor Development in Infant Aged 3-6 Months. . Journal of Maternal and Child Health, 1(3), 161-169.

Lestari, S. B. (2014). Fashion sebagai Komunikasi Identitas Sosial di
Kalangan Mahasiswa. Ragam Jurnal Pengembangan Humaniora, 14(3), 225238.

Maharani, S. (2012). Pijat Dan Senan Sehat Untuk Bayi. Jogjakarta: Kata Hati.

Nedra, W. Soedjatmiko \& Firmansyah, A. (2006). Kesiapan Fisik dan Pengetahuan Remaja Perempuan Sebagai Calon Ibu dalam Membina Tumbuh Kembang Balita dan Faktor-Faktor yang Mempengaruhinya. Sari Pediatri, 8, 209217.

Ngastiyah. (2013). Perawatan Anak Sakit Edisi 2. Jakarta: EGC.

Prasetyono, D. S. (2009). Teknik-Teknik tepat memijat bayi sendiri.

Roesli, U. (2010). Pedoman pijat bayi edisi revisi. Jakarta: PT Trubus Agriwidya.

Shofa, L., \& Yunani, H. R. (2014). Pengaruh Pijat Bayi terhadap Kualitas Tidur Bayi Usia 3-6 Bulan di Poliklinik Kesehatan Desa Purworejo Kecamatan Bonang Kabupaten Demak.

Subakti, Y. \& Anggraini, D. R. (2008). Keajaiban Pijat Bayi \& Balita. Jakarta: Wahyu Media. 